\title{
The development of Bio-Gamyx module for teaching and learning Biology
}

\author{
Nur Izwani Mohd Shapri, ${ }^{1 *}$ Che Nidzam Che Ahmad, ${ }^{2}$ \\ ${ }_{1,2}$ Department of Biology, Faculty of Science and Mathematics, \\ Sultan Idris Education University, Tanjong Malim,35900, Malaysia \\ *email : izwanishapri@gmail.com
}

DOI: https://doi.org/10.37134/jpsmm.vol9.2.1.2019

Published: 29 November 2019

\begin{abstract}
The aims of this study were to develop and validate Bio-GamyX module in teaching and learning Biology for form four students. This module was developed for the topic Chemical Composition of the Cell based on the integration of Sidek and Jamaludin's Model and the Five Steps of Applying Gamification in Education proposed by Huang and Soman. The process of developing this module involved the preparation of module draft, experts' reviews and calculation of content validity of the module. During this process, the module draft was given to three subject matter experts consist of academicians and practitioners to be reviewed. Several recommendations were identified and amendment was done accordingly. The amended module was then evaluated for its content validity. The percentage of experts' agreement obtained for this module ranged from $77 \%$ to $85 \%$. This finding shows that Bio-GamyX module has a good content validity. This finding reinforces the use of gamification approach in the design of teaching and learning modules specifically in Biology subject.
\end{abstract}

Keywords: Gamification, Module Development, Biology Teaching, Module Validation, Chemical Composition in Cell.

\begin{abstract}
Abstrak
Kajian ini bertujuan untuk membangunkan sebuah modul pengajaran dan pembelajaran dalam subjek Biologi Tingkatan Empat yang dikenali sebagai modul Bio-GamyX. Modul ini dibina bagi tajuk Komposisi Kimia dalam Sel berdasarkan kepada integrasi Model Pembangunan Modul Sidek dan Jamaludin dan Lima Langkah Mengaplikasi Gamifikasi dalam Pembelajaran oleh Huang dan Soman. Proses pembangunan modul ini melibatkan peringkat penyediaan draf modul, penilaian pakar dan penentuan kesahan modul. Modul ini dinilai oleh tiga orang pakar bidang yang terdiri daripada ahli-ahli akademik dan guru cemerlang Biologi. Pandangan pakar dikenalpasti dan pembetulan dibuat bagi memastikan modul ini mempunyai nilai kesahan yang baik. Berdasarkan kaedah pengiraan peratus persetujuan pakar, nilai kesahan modul Bio-GamyX adalah dalam julat 77 peratus hingga 85 peratus. Dapatan ini menunjukkan bahawa modul Bio-GamyX mempunyai nilai kesahan yang baik. Kajian ini diharapkan dapat menyumbang kepada aspek penggunaan pendekatan gamifikasi dalam pembelajaran Biologi dalam bentuk pengajaran bermodul.
\end{abstract}

Kata kunci: Gamifikasi, Pembangunan Modul, Pengajaran Biologi, Kesahan Modul, Komposisi Kimia dalam Sel. 


\section{INTRODUCTION}

Teachers nowadays need to realize that traditional teaching methods are no longer the best teaching practice in the classroom in order to meet the needs of new generation (Ismail, 2015). Students found to be demotivated when teachers practicing traditional method (Legault, Green-Demers, \& Pelletier, 2006) as this approach could give impact on students' attitudes in the subject learned. According to Kamisah, Zanaton and Lilia (2007), student attitudes towards self-concept and motivation in learning affects their achievement and involvement in science at higher education levels. As for this concern, one of the promising solutions would be is to apply gamification into teaching and learning practice as gamification has the ability to motivate and engage students in their academic activities (Lee \& Hammer, 2011). Gamification has been implemented in teaching and learning in order to increase intrinsic motivation among students (McGrath \& Bayerlein, 2013; Hussain et al., 2014; Rose, 2015), engage them in learning activities (Da Rocha Seixas et al., 2016; Vandermaas-peeler, 2012) and increase students' performance (Cugelman, 2013; Ong et al., 2013; De Sousa Borges et al.,2014). Although widely implemented in other countries, gamification is relatively a new concept among teachers in Malaysia (Ong et al., 2013).

For nearly ten years ago, gamification raises in prominent as a trending approach in education since the term 'gamification' was introduced by Nick Pelling at the TED (Technology, Entertainment, Design) seminar in 2002. Gamification can be defined as the use of game elements in non-gaming settings (Deterding, Dixon, Khaled, \&Nacke, 2011). Gamification is widely implemented in various fields such as education, health, marketing and military. As for educational purposes, the use of gamification in the process of teaching and learning aims to give students the opportunities to choose, to explore and be rewarded of their efforts (Haskell, 2012). Thus, gamification could increase students' engagement in academic activities, enhance motivation, encourage them to learn and help in problem solving (Kapp, 2012).

Gamification in the context of educational setting uses game design elements usually found in digital games such as rewards, point systems, badges, level, challenges, and leaderboards in the development of learning design (Zichermann \& Cunningham, 2012). Gamification has the ability to create the sensation of excitement and fun (McGonigal, 2011), thus giving the psychological effects on students to avoid boredom during teaching and learning process. The use of gamification creates loyalty among students in academic activities as it is known as an emerging phenomenon in teaching and learning area (Werbach \& Hunter, 2012).

\section{RESEARCH PROBLEM}

Despite the great interest of applying gamification approach in teaching and learning (Seaborn \& Fels, 2015), research on gamification in instructional setting are still few in Malaysia (Ong et al., 2013). Although the use of gamification in education field has caught intentions among educators, research done to confirm its effectiveness towards students' motivation, engagement and achievement are contradicts (Hanus \& Fox, 2015; Van Eck, 2011; Chee, 2012; Erenli, 2013 \& Goodwin, 2013).In addition, most previous research on gamification in learning mainly focused on the effects of using gamification apps (Harrold, 2015, Farozi, 2016; Prasetyo, 2016; Armier, Shepherd, \&Skrabut, 2016) and the use of gamification elements in digital learning environments (Wang, 2012; Wong, Maizatul Hayati \& Tan, 2015).

In Malaysia, teachers perceived gamification as a new teaching and learning pedagogical approach (Ong, Yeng, Hong, \& Young, 2013). Hence, teachers need a step-by-step guide in a form of instructional module to enhance their knowledge and skills to apply gamification in classroom. However, the implementation of gamification approach in classroom always led to failure as it was designed by those who were not involve in education field (Cugelman, 2013). In light of this scarcity, the development of a module of teaching and learning by using gamification approach (Bio-GamyX) is a need in order to implement gamification in teaching and learning Biology. This module also provides guidance for teachers and students to experience a structured gamified learning. 


\section{THE OBJECTIVES OF THE STUDY}

Following the review of the related literature, two objectives of the study were formulated as follows:

1. To develop a Bio-GamyX teaching and learning module for form four students in Biology.

2. To determine the validity of the Bio-GamyX teaching and learning module.

\section{METHODS}

The development of Bio-GamyX module consists of two phases. The first phase was exploring and evaluating the current needs for using gamification approach in teaching and learning Biology subject. In this phase, a need analysis was carried out using questionnaires developed by the researcher. The questionnaires were administered to 20 Biology teachers and 30 form four students who learns Biology as one of their elective subjects. The data collected were then analyzed by using SPSS version 22 software to analyze the quantitative data. Based on the analyzed data, there was a need to apply gamification approach in teaching and learning Biology as most of the respondents reported that teaching and learning Biology subject is boring for both teachers and students. Based on the need analysis, the researcher also found out that the students feel demotivated especially when learning the topic Chemical Composition of the Cell due to abstract concepts and many facts to be remembered in the syllabus. The development of Bio-GamyX module is also using the synthesis of current and relevant literature to help the researcher to develop the module based on the theories and previous research on gamification approach in education.

\section{Theoretical Foundation of Bio-GamyX Module using Gamification Approach}

\section{Sidek and Jamaludin's model of module development}

The second phase was the development of Bio-GamyX teaching and learning draft module based on the Sidek and Jamaludin's model of module development. This model was embedded with the Five Steps of Applying Gamification in Education by Huang and Soman (2013). The teaching and learning module contain two sections and eight main units of activities in a form of series of lesson plans for form four Biology students. The Sidek and Jamaludin's model has proposed a systematic process to develop a module. To prepare a comprehensive module draft, this model suggests the nine steps: 1) goal building, 2) identifying theories, rationales, philosophies, concepts, targets and timeframes, 3) need analysis, 4) setting objectives, 5) content selection, 6) strategy selection,7) logistics selection, 8)media selection and 9) combining the module draft. This model is used as a framework in developing a good quality teaching and learning module.

\section{Five Steps of Applying Gamification in Education by Huang and Soman (2013)}

In order to apply gamification in teaching and learning Biology specifically in classroom setting, the Five Steps of Applying Gamification in Education proposed by Huang and Soman (2013) is embedded as a basic theoretical guideline in the development of Bio-GamyX module. The Five Steps starts with a good understanding of who the students are and their contexts. Proper understanding of determine factors such as age group, learning abilities, skills, environment, students group size and the time frame of activities are crucial to help in designing a proper gamified lesson plan. A proper planning to use gamification in classroom setting could empower students to achieve the desired learning outcomes. The second step as proposed by Huang and Soman (2013) is defining the learning objectives which comprises of general instructional goal, specific learning goal and the behavioral goal. The success of gamification approach depends on the ability of the instructor to define the learning objectives 
clearly. In this step, the learning objectives stated in this module are derived from the Form Four Biology curriculum specification by the Ministry of Education (2011). The next step is structuring the gamified experience for the students. In this step, the gamified experiences are implemented in classroom setting using stages and milestone as a benchmark for the students to achieve certain learning objectives. Stages and milestone are used by breaking down the sequence of knowledge into several lesson units to make the learning objectives seem more achievable and measurable. The fourth step as proposed by Huang and Soman (2013) is identifying the resources needed to gamify the lesson. In this step, tracking mechanism (point system) is used to measure student progress, to identify clear rules, currency, level and feedback as the resources to gamify the classroom.

The last step is the module designer determined the appropriate gamification elements to be applied in the gamified lesson. The gamification elements known as game mechanics in classroom setting can be categorized as self-elements and social elements. Self-elements such as points, level, badges, virtual goods, storyline, time restriction and aesthetics is used to gamified student individually as he can recognized his individual progression. Whereas social elements such as leaderboards, virtual goods, interactive cooperation and also storyline are the elements to gamified students in groups for social comparison. The use of appropriate game mechanics or gamification elements will ensure the success of gamification process in the classroom. The five steps mentioned are clearly stated in Figure 1.

Figure 1. The Five Steps of Applying Gamification in Education proposed by Huang and Soman (2013).

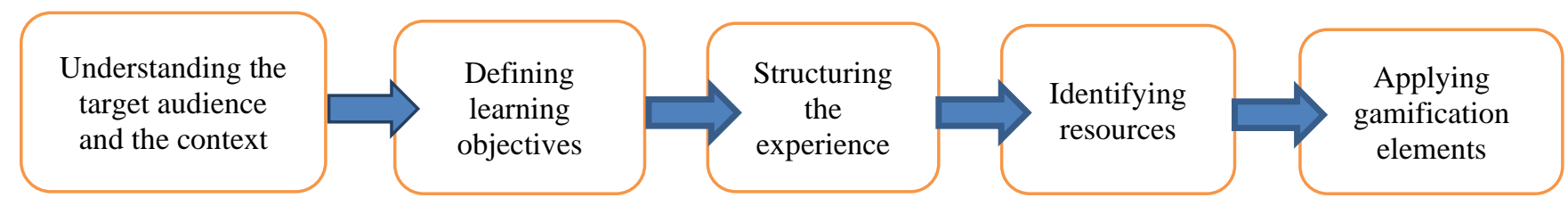

After the researcher has combining the draft of Bio-GamyX module, the module draft content has been validated by three expert panels comprises of the academicians and practitioners. The experts were chosen based on their vast experiences and expertise in module development, biology contents, teaching process and gamification. Each of them was given a copy of complete module draft to be reviewed. Critiques and recommendations by the experts were identified and amendment was done accordingly. The content validity was calculated by using the percentage of experts' agreement. The content validity is considered high if the values exceed the threshold of $70 \%$ (Sidek \& Jamaludin, 2005; Tuckman \& Waheed, 1981).

\section{FINDINGS}

\section{A. Characteristics of Developed Bio-GamyX Module}

This module covers the whole topic of Chemical Composition of the Cell in Biology syllabus for form four students. Basically, the contents of the module are divided into two parts. The first part is for the introduction and also the manual to use the module. The second part is about teaching and learning activities using gamification approach.

The first part of the module provides a detailed guidance on module usage procedures in order to enhance the users' knowledge on gamification approach in teaching and learning process. This part contains the introduction of the module, module's philosophy, an overview of gamification approach in teaching and learning, rationale and objectives of the module, and a manual on using this module for teacher and students.

The purpose of part two is to facilitate the teacher to use the gamification approach in teaching and serve as a platform for the students to experience a gamified lesson. The first section of this second part is storyline. The storyline is used to attract student into the gamified lesson. In the 
storyline, every student plays a role as a tribe member. They were divided into three tribes known as Karbo tribe, Proto tribe and Lipo tribe who compete with one another to search for the five keys to save their nation. They only can get one key each time they completed each unit or level of the lesson. After the storyline section, the next section consisting of gamified learning activities presented in the form of daily lesson plans for the whole topic of the Chemical Composition of the Cell. These activities are divided into five levels. The five levels were named according to the keys they should search in this gamified learning, namely: 1) Curiosity Key 2) Honesty Key 3) Gratitude Key 4) Critical Key and 5) Wisdom Key. The names of the key are derived from the scientific values in learning science in order to expose the values in students.

The levels from one to five indicate the increasing of learning difficulties from the first level to the last. Each level consists of several minds-on and hands-on activities according to the level of difficulties. In level one, the suggested activities are board game activities to explore the chemical compositions in a cell. As for level two, students need to investigate the characteristics and molecular functions of carbohydrate. For level three, the investigations proceed to understanding the molecular structure of protein and its function. After completed level three, students need to investigate the characteristics and biochemical side of lipid in level four. In the last level, students need to identify, investigate and apply the knowledge of enzymes in several experiment activities in lab. The module ended when students completed final quest where they were tested on their understanding of the learning process from level one to five. Student who completed the level fastest will win this challenge. The winner is indicated when he will be given the honor to unlock the Magical Chest at the end of the challenge by using the five keys he has collected in series of the previous levels. To give a comprehensive overview of the module, Table I is referred.

Table 1. The sections of Bio-GamyX module.

\begin{tabular}{lll}
\hline \hline \multicolumn{1}{c}{ First Part } & \multicolumn{1}{c}{ Second part } \\
\hline - Introduction & $\bullet$ & Storyline \\
- Brilosophy & Brief overview of gamification & - Level 1: Curiosity Key \\
approach & - Level 2: Honesty Key \\
- Overview of module & Rationale of module & Level 4: Critical Key \\
- Objectives of module & - Level 5: Wisdom Key \\
- Guidelines to use module for teacher & - Unidelines to use module for student & \\
\hline
\end{tabular}

To give an overview of Bio-GamyX module, examples of the contents in this module is illustrated in Figure 2 as follows.

Figure 2. Examples of contents in Bio-GamyX module.
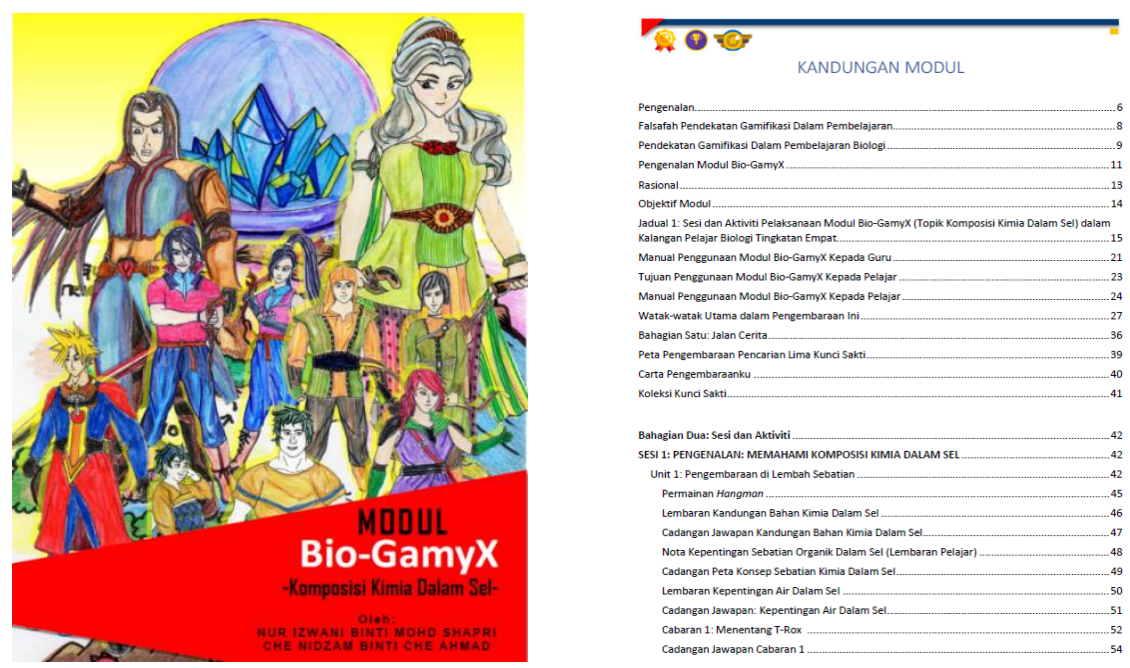

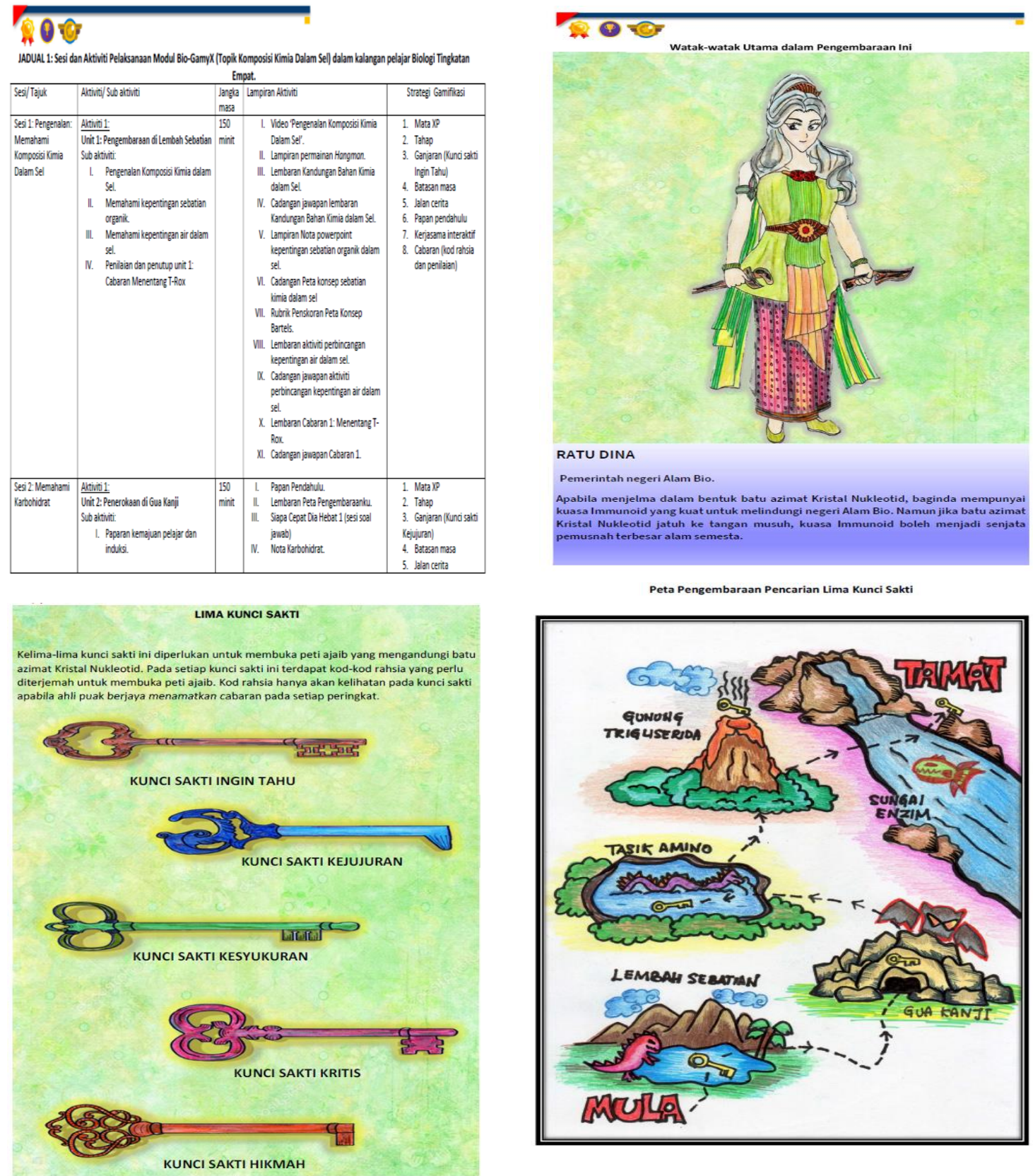

\section{B. Validity of Bio-Gamyx module}

The content of Bio-GamyX module has been validated by three experts comprised of academicians and practitioners. This module is validated in two dimensions including content knowledge and module activities. Expert recommendations are gathered to find similarities in ideas for identifying improvements that need to be made. Amendment was done according to the suggestions of the expert. The results after computing the content validity of this module are above the threshold value of $70 \%$ (Sidek \&Jamaludin, 2005; Tuckman \& Waheed, 1981), ranging from $77 \%$ to $85 \%$. Thus, this finding shows that Bio-GamyX module developed has a good content validity. 


\section{CONCLUSION}

In this study, Bio-GamyX module is feasible to be use in teaching and learning Biology. Teacher and students have the opportunities to experience gamified learning through minds-on and hands-on activities which were embedded with gamification elements at each stage of learning. Moreover, this module has been validated to possess high content validity by the judgement of the experts. Thus, the module in this study will act as a catalyst for more research on gamification approach in teaching and learning specifically for Biology learning in secondary school.

\section{REFERENCES}

Armier, D., Shepherd, C. E., \& Skrabut, S. (2016). Using Game Elements to Increase Student Engagement in Course Assignments. College Teaching, 64(2), 64-72

Bahagian Pembangunan Kurikulum (2011). Spesifikasi Kurikulum Biologi Tingkatan Empat.Putrajaya: Kementerian Pendidikan Malaysia.

Biro, G. I. (2013). Ready, Study, Share: An Inquiry Into the Didactic Approach of Gamification With a Special View to the Possible Application in Higher Education, 1st Annual International Interdisciplinary Conference, Conference Proceedings, Vol.2, EGALITE, European Scientific Institute Publishing.

Chee, Y. S., \& Tan, D. K. C. (2012). Becoming chemists through game-based inquiry learning: The case of Legends of Alkhimia.

Cugelman, B. (2013) Gamification: What it is and why it matters to digital health behavior change developers. JMIR Serious Games, 1(1), e3.

Da Rocha Seixas, L., Gomes, A. S., \& De Melo Filho, I. J. (2016). Effectiveness of gamification in the engagement of students. Computers in Human Behavior, 58(January), 48-63

De Sousa Borges, S., Durelli, V. H., Reis, H. M., \&Isotani, S. (2014, March). A systematic mapping on gamification applied to education. In Proceedings of the 29th Annual ACM Symposium on Applied Computing (pp. 216-222). ACM.

Deterding, S., Dixon, D., Khaled, R., \& Nacke, L. (2011). From game design elements to gamefulness: Defining gamification. Proceedings of the 15th International Academic MindTrek Conference on Envisioning Future Media Environments - MindTrek'11, 9-11.

Erenli, K. (2013). The impact of gamification-recommending education scenarios. International Journal of Emerging Technologies in Learning (iJET), 8(S1), 15-21.

Farozi, M. (2016). Rancang Bangun Website Gamifikasi Sebagai Strategi Pembelajaran dan Evaluasi Hasil Belajar Mahasiswa. Sumatera Selatan, Indonesia: Amik Lembah Dempo.

Goodwin, B., \& Miller, K. (2013). Evidence on flipped classrooms is still coming in. Educational Leadership, 70(6), 78-80.

Harrold, D. J. (2015). Game on: A qualitative case study on the effects of gamified curriculum design on student motivational learning habits. (PhD Dissertation) Robert Morris University

Haskell, C.C.(2012). Design Variables of Attraction in Quest-Based Learning. Boise State University Theses and Dissertations. Available at: http://works.bepress.com/chris_haskell/14/

Hong, G. Y., \& Masood, M. (2014). Effects of Gamification on Lower Secondary School Students' Motivation and Engagement. World Academy of Science,Engineering and Technology, International Journal of Social, Behavioral,Educational, Economic, Business and Industrial Engineering, 8(12), 3733-3740.

Huang, W.H.Y, \&Soman, D. (2013). A practitioner's guide to gamification of education. Toronto, ON, Canada: Rotman school of management.

Hussain, S. Y. S., Tan, W. H., \& Idris, M. Z. (2014). Digital game-based learning forremedial mathematics students: A new teaching and learning approach InMalaysia. International Journal of Multimedia Ubiquitous Engineering, 9(11),325-338.

Lee, J. J., \& Hammer, J. (2011). Gamification in education: What, how, why bother?Academic exchange quarterly. 15(2),146.

Kamisah Osman, Zanaton Iksan, \& Lilia Halim. (2007). Sikap terhadap Sains dan Sikap Saintifik di kalangan Pelajar Sains.Jurnal Pendidikan, 32, 39-60.

Kapp, K. M. (2012). The gamification of learning and instruction: game-based methods and strategies for training and education. John Wiley \& Sons.

McGonigal, J. (2011). Reality is broken: Why games make us better and how they can change the world. Penguin.

McGrath, N., \&Bayerlein, L. (2013). Engaging online students through the gamification of learning materials: The present and the future. Sydney: H.Charter; M. Gosper; J. Hedberg, 573-577. 
Ong, D., Yeng, C. Y., Hong, C. W., \& Young, K. T. (2013). Motivation of Learning: an Assessment of the Practicality and Effectiveness of Gamification Within a Tertiary Education System in Malaysia. World Academy of Researchers, Educators, and Scholars in Business, Social Sciences, Humanities and Education (In Association with the Academy of World Finance, Banking, Management and IT) Conference Proceedings, 1(1), 131-146.

Prasetyo, I.A. (2016). Penerapan Konsep Gamifikasi pada Perancangan Aplikasi Pembelajaran Al-Quran. Seminar Nasional Teknologi Informasi dan Multimedia.

Rose, J. A. (2015). Gamification of Physics Education: Enhancing Student LearningWith Gamified Online Quizzes.

Sidek Mohd Noah \& Jamaludin Ahmad. (2005). Pembinaan Modul: Bagaimana Membina Modul Latihan dan Modul Akademik (Ulang cetak). Serdang: Penerbit Universiti Putra Malaysia.

Tuckman, B.W.\& Waheed, M.A. (1981). Evaluating an Individualized Science Programme for Community College Students. Journal of Research in Science Teaching. 18, 489-495.

Vandermaas-Peeler, M., Ferretti, L., \& Loving, S. (2012). Playing The LadybugGame: parent guidance of young children's numeracy activities. Early Child Development and Care, 182(10), 1289 -1307.

Van Eck, R. N. (2011). Bringing 'discipline' to the study of games and learning. Information Design Journal, 19(2), 181.

Wang, Z., Bergin, C., \& Bergin, D. A. (2014). Measuring engagement in fourth to twelfth grade classrooms: The classroom engagement inventory. School Psychology Quarterly, 29(4), 517-535.

Werbach, K., \& Hunter, D. (2012). For the win: How game thinking can revolutionize your business. New York: Wharton Digital Press.

Wong, Y. S., MaizatulHayati Mohamad Yatim, \& Tan, W. H. (2015). Learning Object-Oriented Programming with Computer Games: A Game-Based Learning Approach. In European Conference on Games Based Learning (p. 729). Academic Conferences International Limited.

Zichermann, G., \& Cunningham, C. (2011). Gamification by design: Implementing game mechanics in web and mobile apps. O'Reilly Media, Inc. 